\title{
BIODEGRADATION OF ENERGY PLANTS SUBSTRATES WITH CULINARY-MEDICINAL MUSHROOMS
}

\author{
G. Grodzynska ${ }^{1}$, M. Lomberg ${ }^{2}$, D. Rahmetov ${ }^{3}$, V. Nebesnyi ${ }^{1}$ \\ ${ }^{1}$ Інститут еволюційної екології НАН України \\ ${ }^{2}$ Інститут ботаніки імені М.Г. Холодного НАН України \\ ${ }^{3}$ Національний ботанічний сад ім. М.М. Гришка НАН України
}

\begin{abstract}
Культивування цінних їстівних та лікарських грибів (Pleurotus ostreatus, Pleurotus eryngii, Flammulina velutipes $i$ Ganoderma lucidum) на енергетичних рослинах селекції НБС ім. М.М. Гришка засвідчило, що субстрати з Sorghum saccharatum i Camelina sativa виявилися найпридатнішими для росту досліджених штамів. Первинна деградація субстратів з енергетичних рослин міцелієм лігнотрофних базидіальних грибів є підготовкою иієї сировини для подальшого каскаду біохімічних перетворень із залученням угруповань різних систематичних груп мікроміцетів та бактерій для утворення у біореакторах кінцевого біопаливного продукту.
\end{abstract}

Ключові слова: енергетичні рослини, їстівні та лікарські гриби, біопаливо.

The processes of decomposition of cellulose and lignin, the most stable natural polymers, and at the same time, the main components of vegetation and wood, which accumulate annually in huge amounts on the Earth, have attracted the attention of scientists during the last decades. The ability to effectively degrade lignocellulosic substrates by basidial macromycetes opens up wide possibilities for their use in biotechnologies for the processing and utilization of waste from the agro-industrial complex. Taking into account the darting growth of biofuel production in the world, development of technologies for biodegradation of essential volumes of unreturned residues of bioenergy plants is actual $[1,2]$. For Ukraine, an important resource for the production of biofuels is the introduction of highly productive varieties of plants from Poaceae, Polygonaceae, Malvaceae, Amaranthaceae, Asteraceae, Fabaceae and Brassicaceae. The collection of energy plants has been created in the M.M. Grishko National Botanical Garden of NAS of Ukraine, and includes 365 species, varieties and forms [1]. Mushrooms using plant residues (including cereal straw, oats, sunflower husk, corn rods, flax, other wastes from the agro-industrial

\footnotetext{
(C) G. Grodzynska, M. Lomberg, D. Rahmetov,

V. Nebesnyi, 2019
}

complex) are a powerful source of extracellular enzymes which are capable to destroy lignocellulose of these substrates to low molecular weight compounds. Today, in addition to valuable nutritional properties of edible species, for mushrooms it is known approximately 130 medicinal functions, including antitumor, immunomodulating, antioxidant, radical scavenging, cardiovascular, anti-hypercholesterolemic, antiviral, detoxification, hepatoprotective, antidiabetic, etc [3, 4]. For these reasons, mushrooms certainly are a valuable biotechnological object.

The aim of present research was the estimation of degradation substrates of energy plants, linear growth rates of mycelium, and obtaining of mushroom biomass (fruit bodies and mycelium) of some culinary-medicinal mushrooms during cultivation on nontoxic residues of energy plants selected in Ukraine.

\section{MATERIALS AND METHODS}

To study the growth rates, biodegradation of substrates and fructification, pure cultures of four species of culinary-medicinal mushrooms - Pleurotus ostreatus (Jacq.) P. Kumm (strain 198), P. eryngii (DC.) Quél. (strain 2011), Ganoderma lucidum (Curtis) P. Karst. (strain 1621), and Flammulina velutipes (Curtis) Singer (strain 1994) were 
used. Mushrooms cultures were obtained from the IBK Mushroom Culture Collection of M.G. Kholodny Institute of Botany NAS of Ukraine. The growth and cultural peculiaritiers during cultivation on non-toxic residues of energy plants of M.M. Grishko National Botanical Garden selection such as Sorghum saccharatum (L.) Moench (variety «Botanichnyi») - SS, Camelina sativa (L.) Krantz. («Peremoga») - CS Shchavnat (Rumex patientia L. x R. tianschanicus Losinsk.) («Rumex OK-2») - RR, and Sida hermaphrodita Rusby («Fitoenergiya») - $\boldsymbol{S H}$ were studied. The disks of mycelium with a diameter of $1 \mathrm{~cm}$ were placed on sterilized media or substrates (in different variants) and grown at $25 \pm 0.5^{\circ} \mathrm{C}$.

\section{RESULTS AND DISCUSSION}

According to P. Baldrian [5], fungi play an important role in the processes of lignocellulose transformation in the natural environment due to their ability to simultaneously destroy both polysaccharides and polyphenols in the organic layer of soil. At the same time, as some of the main provisions of the regulation of enzyme activity are clear, the question of the production and diversity of enzymes at the molecular level remains open. Unlike other researchers, this author emphasizes that in the processes of decomposition of lignin and cellulose not only the saprotrophic basidiomycetes and ascomycetes are involved, but the contribution of ectomycorrhizal fungi can also be significant $[5,6]$. V. Elisashvili, and G. Kvesitadze pay a special attention to cultivated culinary-medicinal species of Pleurotus ostreatus and Lentinus edodes, their biotechnological potential as a source of oxidative and hydrolytic enzymes. The authors propose the use of substrates after their cultivation and harvesting as a cheap source of lignocellulolytic enzymes, in particular, for bioremediation. Enzymatic degradation of lignocellulosic substrates is carried out mainly with the participation of oxidoreductases and hydrolases, which also determines the significance of these enzymes in the process of biodegradation of polymers and xenobiotics that are difficult to hydrolyze
[7]. I. Pavlov et al. [8] note that the leading mechanism of bioconversion is the action of a multi-enzyme complex whose synthesis depends on the growth substrate, physiological and biochemical characteristics of the producer strain and its genetic features.

First of all, the linear growth rate of selected mushroom strains pure cultures on agar medium with the addition of aqueous extracts of the investigated substrates at a temperature of $25^{\circ} \mathrm{C}$ was determined. In this experiments a maximal growth rates for all strains (higher than in the case of control medium $-8^{\circ}$ wort agar) were observed on medium with addition of aqueous extract of $S$. saccharatum. The cultivation of pure cultures of studied strains of lignotrophic mushrooms on pre-shredded $(1-3 \mathrm{~cm})$, moisturized and sterilized substrates from energy plants showed the ability of each species to overgrown the substrates for a certain period of time. It should be noted that the primary volume of substrate significantly decreasing at the end of the experiment (in 1.7-2.8 times) (Fig. 1, 2).

Besides, we studied the mushroom culture growth on the mixed substrates of energy plants and oak sawdust (OS) in ratio 1:1. In a case of $100 \%$ oak sawdust substrate the rate of mycelia growth was strongly suppressed in P. ostreatus and P. eryngii (apparently, it is connected with a low acidity of substrate, $\mathrm{pH}$ 3.8). In other cases, the addition of oak sawdust also inhibited the mycelia growth (pH were in the range of 6 to 6.5 ).

The rates of overgrowing substrates at $25^{\circ} \mathrm{C}$ ranged from 7 days (in $P$. ostreatus) to 12 days ( $F$. velutipes), the fruit bodies appeared in G. lucidum (28 and 35 days) and $F$. velutipes (34 and 38 days) respectively on $S$. saccharatum and $C$. sativa substrates. For the formation of fruitification stage, the mushroom cultures were kept indoors with daylight and at a temperature of $20^{\circ} \mathrm{C}$. It should be noted that among studied lignotrophs, F. velutipes and G. lucidum more actively utilized energy plants substrates and showed high capacity to form fruit bodies in culture (Table). In variants with $P$. ostreatus, which have a maximal rates of overgrowing all sub- 


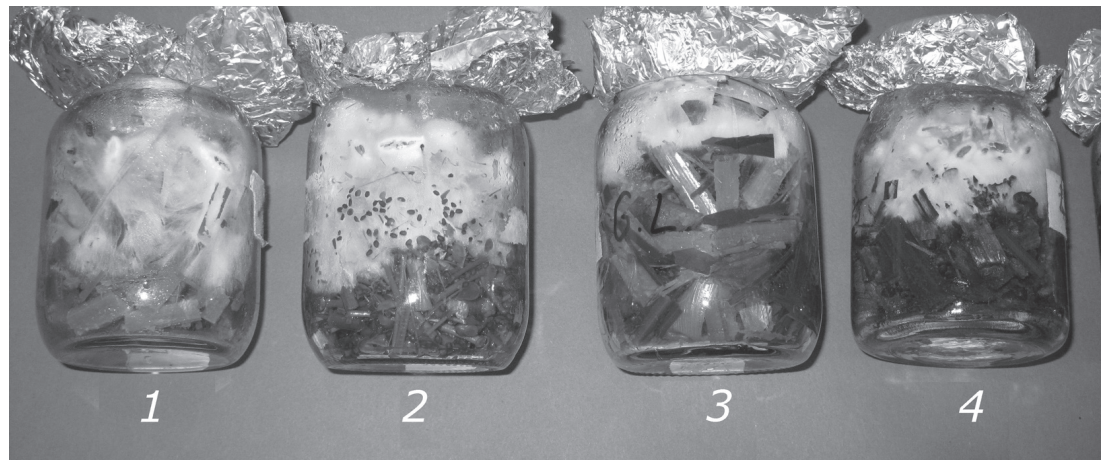

Fig. 1. The overgrowing of substrates from energy plants with mycelium of Ganoderma lucidum: 1 - Sorghum saccharatum (SS), 2 - Camelina sativa $(\boldsymbol{C S}), 3$ - Sida hermaphrodita $(\boldsymbol{S H}), 4-$ Shchavnat $(\boldsymbol{R} \boldsymbol{R})$ (7 day of cultivation)

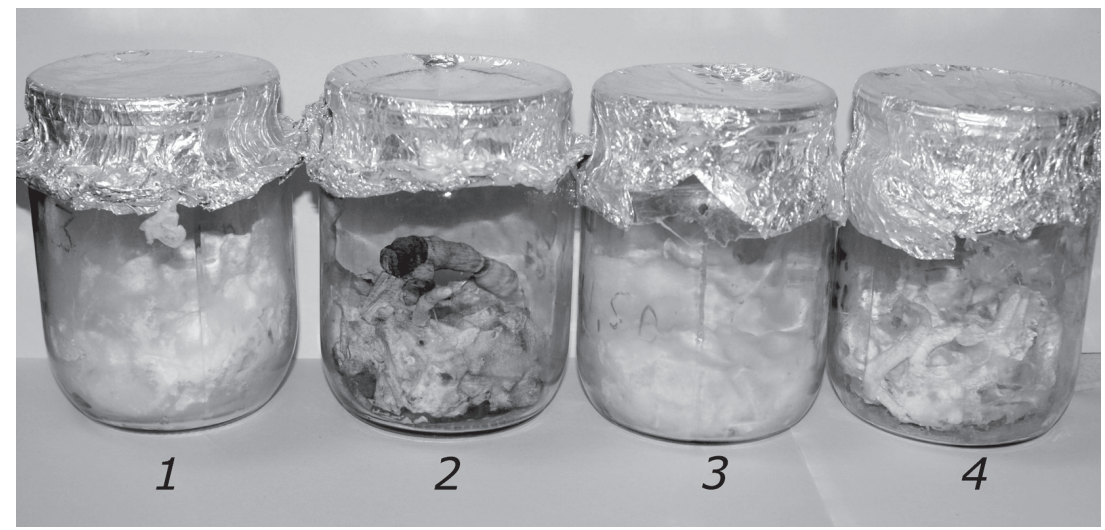

Fig. 2. The overgrowing with mycelium and Ganoderma lucidum fruit bodies formation on energy plants substrates: 1 - Sorghum saccharatum $(\boldsymbol{S S}), 2$ - Camelina sativa $(\boldsymbol{C S}), 3$ - Shchavnat $(\boldsymbol{R} \boldsymbol{R}), 4-$ Sida hermaphrodita $(\boldsymbol{S H})$ (30 days of cultivation)

strates (with the exception of oak sawdust), abundant formation of primordia was observed. Mycelial growth of King Oyster $(P$. eryngii) was most dependent of the substrate, and this species could form fruit bodies on substrates of $\mathbf{S S}$ and $\mathbf{C S}$ (Fig. 3).

Thus, the obtained results indicate that among the investigated substrates, the most promising for biodegradation with lignotrophic mushrooms is Sorghum saccharatum and Camelina sativa. All studied strains showed the overgrowth of substrates of energy plants and a significant decrease of their volumes. Mushroom biomass (fruit body and mycelium) produced as a result of the proposed cycle, grown on non-toxic waste, can also be used in culinary and medicinal aims and as effective fertilizer. Primary biodegradation of energy plants substrates with mycelium of lignotrophic mushrooms is the preparation of this material for the subsequent cascade of biochemical transformations involving groups of different systematic groups of micromycetes (including yeast fungi), bacteria for the formation in the bioreactors of the final biofuel product.

Further studies of biodegradation potential of macromycetes for lignin-cellulose complexes and the development of biofuel mycotechnologies require the selection and study of the cultural features of highly effective strains promising for the production of 
Primordia (P) and fruit bodies (FB) formation of culinary-medicinal lignotroph species on substrates of energy plants and mixture energy plants and oak sawdust substrates

\begin{tabular}{l|c|c|c|c|c|c|c|c|c}
\hline \multicolumn{1}{c}{ Species } & $\boldsymbol{S H}$ & $\boldsymbol{C S}$ & $\boldsymbol{S S}$ & $\boldsymbol{R} \boldsymbol{O}$ & $\boldsymbol{O S}$ & $\boldsymbol{S H}+\boldsymbol{O S}$ & $\boldsymbol{C S}+\boldsymbol{O S}$ & $\boldsymbol{S S + \boldsymbol { O S }}$ & $\boldsymbol{R} \boldsymbol{R}+\boldsymbol{O} \boldsymbol{S}$ \\
\hline \hline Flammulina velutipes & $\mathrm{P}$ & FB & FB & FB & FB & $\mathrm{P}$ & $\mathrm{FB}$ & $\mathrm{FB}$ & $\mathrm{FB}$ \\
Ganoderma lucidum & $\mathrm{P}$ & FB & FB & $\mathrm{P}$ & $\mathrm{P}$ & $\mathrm{FB}$ & $\mathrm{FB}$ & $\mathrm{FB}$ & $\mathrm{P}$ \\
Pleurotus eryngii & - & FB & FB & - & - & - & $\mathrm{P}$ & $\mathrm{P}$ & - \\
Pleurotus ostreatus & $\mathrm{P}$ & $\mathrm{P}$ & $\mathrm{FB}$ & $\mathrm{P}$ & $\mathrm{P}$ & $\mathrm{P}$ & $\mathrm{P}$ & $\mathrm{P}$ & $\mathrm{P}$ \\
\hline
\end{tabular}

Note:* $\boldsymbol{S H}$ - Sida hermaphrodita, $\boldsymbol{C S}$ - Camelina sativa, $\boldsymbol{S} \boldsymbol{S}$ - Sorghum saccharatum, $\boldsymbol{R} \boldsymbol{R}$ - Shchavnat (Rumex patientia $\times$ R. tianschanicus), «-»- absence of primordial and fruit bodies.

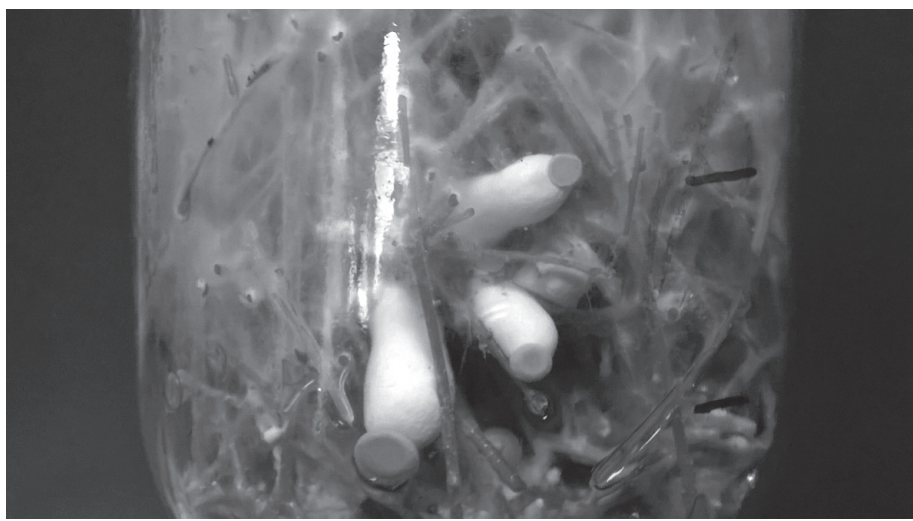

Fig. 3. Fruit bodies formation of Pleurotus eryngii on substrates of Camelina sativa (CS) (48 days of cultivation)

biofuels from energy plants of different uses (plants with high content of sugar, carbohydrate, oil etc.).

\section{CONCLUSIONS}

Among the investigated substrates of energy plants, the most promising for biodegra- dation with studied lignotrophic culinary-medicinal mushrooms are Sorghum saccharatum and Camelina sativa.

Mushroom biomass produced in the proposed cycle, when grown on non-toxic waste, can also be used for food and medical purposes, or as a valuable fertilizer.

\section{ЛІТЕРАТУРА}

1. Рахметов Д.Б. Теоретичні та прикладні аспекти інтродукції рослин в Україні: монографія / Д.Б. Рахметов. - К.: Агар Медіа Груп, 2011. - 398 с.

2. Перспективи використання біоенергетичних культур в Україні / В.П. Ландін, В.В. Мороз, В.А. Захарчук, О.М. Руденко // Наук. вісник НЛтУ України. - 2016. - Вип. 26.5. - С. 8086.

3. Макромицеты: лекарственные свойства и биологические особенности / [под ред. С.П. Вассера]. - К.: Наш формат, 2012. - 285 с.
4. Макромицеты: лекарственные свойства и биологические особенности / [под ред. И. Габриэля]. - T. 2. - К.: Наш формат, 2016. - 261 c.

5. Baldrian P. Production of lignocellulolytic enzymes by mushrooms / P. Baldrian // Proceedings of the $7^{\text {th }}$ Intern. Conf. on Mushroom Biology and Mushroom Products (Arcachon, France, 4-7 Oktober, 2011). - Arcachon: INRA, 2011. - P. 339-343.

6. Baldrian P. Lignocellulose-degradating enzymes in soils / P. Baldrian, J. Šnajdr // Soil Enzymology. - 2011. - Vol. 22. - P. 167-186. 
7. Elisashvilil V. Lignocellulose and white-rot Basidiomycetes: some strategies for their potential utilization / V. Elisashvilil, G. Kvesitadze // Int. Journ. of Medicinal Mushrooms. - 2005. - Vol. 7, No. 3. - P. 344-345.

8. Лигнолитическая активность Porodaedalea nie- melaei M. Fischer при твердофазном культивировании на растительных субстратах / И.Н. Павлов, Ю.А. Литовка, Е.А. Литвинова и др. // Современная микология в России: материалы V Съезда микологов России «Грибные биотехнологии». - Т. 5, Вып. 6. - М., 2015. - С. 337-339.

\section{REFERENCES}

1. Rakhmetov, D.B. (2011). Teoretychni ta prykladni aspekty introduktsii roslyn v Ukraini [Theoretical and applied aspects of plant introduction in Ukraine]. Kyiv: Ahar Media Hrup [in Ukrainian].

2. Landin, V.P., Moroz, V.V., Zakharchuk, V.A. \& Rudenko, O.M. (2016). Perspektyvy vykorystannia bioenerhetychnykh kultur v Ukraini [Prospects for the use of bioenergy crops in Ukraine]. Nauk. visnyk NLTU Ukrainy - Science. Bulletin of the NLTI of Ukraine, Vol. 26.5, 80-86 [in Ukrainian].

3. Vasser, S.P. (Ed.). (2012). Makromitcety: lekarstvennye svoistva i biologicheskie osobennosti [Macromycetes: medicinal properties and biological features]. Kiev: Nash format [in Russian].

4. Gabrijel', I. (Ed.). (2016). Makromitcety: lekarstvennye svoistva i biologicheskie osobennosti [Macromycetes: medicinal properties and biological features]. (Vol. 2). Kiev: Nash format [in Russian].

5. Baldrian, P. (2011). Production of lignocellulolytic enzymes by mushrooms. Proceedings of the Mushroom Biology and Mushroom Products '11: $7^{\text {th }}$ In- tern. Conf. (Arcachon, France, 4-7 Oktober, 2011). (pp. 339-343). Arcachon: INRA [in English].

6. Baldrian, P., Šnajdr, J. (2011). Lignocellulose-degradating enzymes in soils. Soil Enzymology, 22, 167186 [in English].

7. Elisashvilil, V., Kvesitadze, G. (2005). Lignocellulose and white-rot Basidiomycetes: some strategies for their potential utilization. Int. Journ. of Medicinal Mushrooms, 7, 3, 344-345 [in English].

8. Pavlov, I.N., Litovka, Iu.A., Litvinova, E.A., Riazanova, T.V. \&Chuprova N.A. (2015). Lignoliticheskaia aktivnost Porodaedalea niemelaei M. Fischer pri tverdofaznom kultivirovanii na rastitelnykh [Lignolytic activity of Porodaedalea niemelaei M.Fischer under solid-phase cultivation on plant substrates]. Proceedings from Modern Mycology in Russia '15: Materialy V Cezda mikologov Rossii. Gribnye biotekhnologii. (pp. 337-339; Vol. 5, Issue. 6). Moskva [in Russian].

Отримано 29.01.2019 